\title{
PROFILE OF PATIENTS WITH BAGGIO-YOSHINARI SYNDROME ADMITTED AT "INSTITUTO DE INFECTOLOGIA EMILIO RIBAS"
}

Emy Akiyama GOUVEIA(1), Mayra Fernanda ALVES(2), Elenice MANTOVANI(2), Luiza Keiko OYAFUSO(3), Virgínia Lucia Nazario BONOLDI(2) \& Natalino Hajime YOSHINARI(2)

\begin{abstract}
SUMMARY
The aim of this study was to evaluate the epidemiological, clinical and laboratorial profile of patients with Baggio-Yoshinari Syndrome (BYS), who underwent internment at the Instituto de Infectologia Emilio Ribas in São Paulo, Brazil, during the period from July 1990 to July 2006. BYS is a new Brazilian tick-borne disease caused by Borrelia burgdorferi sensu lato microorganisms that resembles features of Lyme disease (LD), except for its epidemiological, clinical and laboratorial particularities. From 60 patients' records with positive serology to B. burgdorferi done by ELISA and Western-blotting methods, 19 cases were diagnosed as having BYS, according to criteria adopted at LIM-17 HCFMUSP, the Brazilian Reference Laboratory for the research of BYS. The other 41 remaining patients displayed miscellaneous infections or auto-immune processes. The beginning of symptoms in BYS group varied from one day to six years, from the onset of the disease. Four of 19 patients were included in acute disease stage, and 15 in latent. General unspecific symptoms were identified in almost all cases, with high frequencies of fever (78.9\%) and lymphadenomegaly (36.8\%). Six patients had skin lesions (31.5\%); six arthralgia or arthritis (31.5\%) and eight neurological symptoms (42\%). Interestingly, two patients showed antibodies directed to B. burgdorferi exclusively in cerebrospinal fluid. Since BYS is a new emergent Brazilian zoonosis and its diagnosis is sometimes complex, all the new knowledge about BYS must be scattered to Brazilian Medical specialists, aiming to teach them how to diagnose this amazing tick-borne disease and to avoid its progression to chronic irreversible sequels.
\end{abstract}

KEYWORDS: Lyme Disease; Lyme disease-like illness; Baggio-Yoshinari Syndrome; Tick-borne diseases; Borrelia burgdorferi; Brazil.

\section{INTRODUCTION}

Lyme Disease (LD) is a frequent zoonosis transmitted by Ixodes ricinus complex ticks, caused by Borrelia burgdorferi sensu lato complex microorganisms, constituted by at least 11 spirochete species. B. burgdorferi sensu stricto is identified in the United States of America (USA) and Eurasia, while B. afzelii and B. garinii in Europe and Asia ${ }^{2,8,36,37}$. Skin and joint symptoms are predominant in the USA, while neurological disorders are more frequent in Europe ${ }^{2,13,21}$.

A similar zoonosis called Lyme disease-like Illness or Masters' Disease, also known as Southern Tick-Associated Rash Illness (STARI) has been reported in the south of USA ${ }^{27}$, caused by B. lonestari, which is a spirochete uncultivable in BSK medium and genetically similar to B. theileri, found in cattle. STARI is transmitted by the Amblyomma americanum tick, and the clinical picture is characterized by the appearance of erythema migrans (EM), without jeopardy of internal organs. Furthermore, patients with STARI do not develop antibodies to B. burgdorferi.
The proposal of LD research in Brazil emerged in 1989, with the gathering of a multidisciplinary team ${ }^{39}$. The group intended to identify patients in Brazil and to perform microbiological and diagnostic tests. In 1990, the Laboratório de Investigação em Reumatologia do Hospital das Clínicas da Faculdade de Medina da Universidade de São Paulo (LIM17 HCFMUSP) was considered by the Brazilian Health Department as Reference Laboratory to research and to assist suspected patients.

In 1992, the first cases of Brazilian LD were described ${ }^{40}$, admitted to the Instituto de Infectologia "Emilio Ribas" (IIER). These young patients presented fever, erythema migrans (EM) and arthritis, and the diagnosis was confirmed at the LIM-17 HCFMUSP Lab by ELISA and Westernblotting (WB) assays, using B. burgdorferi sensu stricto antigens of North American origin, originally isolated from the tick Ixodes scapularis. Since then, many other cases were reported, all of them exhibiting similar clinical features of LD, including presence of EM and systemic articular, neurological and cardiac symptoms $\mathrm{s}^{5,11,34,41,42,43,45,47}$.

However, along the years, many distinguishing features were

Financial support: Fundação de Amparo à Pesquisa do Estado de São Paulo (FAPESP).

(1) Hospital Estadual Mário Covas.

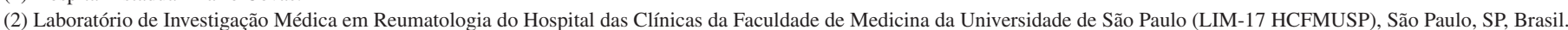

(3) Instituto de Infectologia Emílio Ribas, São Paulo, SP, Brasil.

Correspondence to: Natalino Hajime Yoshinari, Faculdade de Medicina da Universidade de São Paulo, Av. Dr. Arnaldo 455, $3^{\circ}$ andar, sala 3184. E-mail: yoshinari@lim17.fm.usp.br 


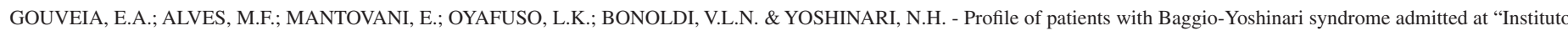
de Infectologia Emilio Ribas". Rev. Inst. Med. Trop. Sao Paulo, 52(6): 297-303, 2010.

identified in Brazil. B. burgdorferi had never been isolated or cultured in BSK, even when many enriched media were employed to culture biological materials from patients ${ }^{12,38}$, potential reservoir animals ${ }^{1}$ or ticks collected at risk areas ${ }^{6}$.

Ticks from Ixodes ricinus complex, the main invertebrate hosts involved in Borrelia transmission in USA and Eurasia, had never been found biting people at risk areas. On the contrary, it was reported emergence of Brazilian LD in a laboratory researcher, accidentally bitten by Amblyomma cajennense tick (Yoshinari NH-personal communication). Ticks of genus Rhipicephalus were also suspected to transmit spirochetes, due to coexistence of antibodies to B. burgdorferi and Babesia bovis in Brazilian LD patients ${ }^{44}$.

Molecular Biology studies (PCR) performed by $\operatorname{COSTA}^{10}$ and BARROS $^{4}$ using human and ticks samples revealed negative results, when primers to amplify conservative specific genes of $B$. burgdorferi were used. The primers employed were targeted to identify outer surface protein $\mathrm{A}(\mathrm{OspA})^{22}$ and genes for major flagellin FlaB and minor flagellin $\mathrm{FlaA}^{20}$, as well as for ribosomal $16 \mathrm{~S} \mathrm{rRNA}^{3}$.

Clinically, Brazilian LD-like patients present increased frequency of relapsing episodes, especially if the disease is unrecognized at an early stage or wrongly treated. Furthermore, in most of cases, antibiotic treatment is not efficient to cease recurrent disease symptoms. Allergic manifestations including acquired angioedema, have been also described along the disease progression ${ }^{17,42,45,47}$.

Laboratorial assays to diagnose Brazilian LD-like illness is a very complex question, since antibodies against B. burgdorferi sensu lato identified by ELISA or Western-blotting procedures offer low sensitivity and specificity ${ }^{42,47}$. In this respect, when both assays are employed together in Brazilian patients, the positivity reaches only $65 \%$ of cases, while in a normal control group the frequency is around $16 \%{ }^{25}$. However, serological diagnostic procedure for LD diagnosis in USA based on two-tier algorithm using ELISA or IFA (immunofluorescence assay) as screening tests and WB as confirmatory assay is also considered inadequate for clinical purposes ${ }^{19}$. Another important laboratorial aspect in Brazil is the demonstration of autoimmune disorders, including the emergence of antinuclear antibodies (ANA), anticardiolipin, anti-neutrophil cytoplasmic antibodies (ANCA), and antineuronal antibodies in the blood of patients ${ }^{17,42}$.

MANTOVANI et al. ${ }^{24}$ had described structures resembling Mycoplasma spp, Chlamydia spp and long bacterium-like microorganisms in the peripheral blood of patients by electron microscopy analysis. Since serologic and PCR assays did not confirm presence of these latent bacteria, researchers from LIM-17 HCFMUSP proposed that etiological agent found in Brazil could be expressed at atypical morphologies ${ }^{46}$.

MANTOVANI ${ }^{26}$ in her $\mathrm{PhD}$ thesis, presented to Faculdade de Medicina da Universidade de São Paulo, identified the etiological agent as spirochete belonging to B. burgdorferi sensu lato complex, executing a PCR assay, employing a conserved gene that synthesizes the flagellar hook (flgE) $)^{30}$ (unpublished data). Other preliminary unpublished results also showed that ticks from genus Rhipicephalus and domestic animals like horses and bovines were infected by microorganisms and can participate in the epidemiological process of this emergent Brazilian tick borne disease.
Due to these many particularities, this tick-borne zoonosis found in Brazil, was assumed to be an exotic infectious disease, and thus, in an attempt to distinguish it from classical LD was named Baggio-Yoshinari Syndrome $(B Y S)^{16}$. Currently, BYS is defined as a new Brazilian tickborne disease that imitates clinical and laboratorial features of LD, caused by $B$. burgdorferi sensu lato spirochete, possibly at its atypical morphologies and being transmitted by ticks of genus Rhipicephalus and Amblyomma, thus not belonging to Ixodes ricinus complex.

We assume that Brazilian biodiversity and distinct geographic conditions, especially the occurrence of exotic tick species and animal reservoirs, originated mutant $B$. burgdorferi adapted to survive in the country. Mutant Borrelias with genetic changes at its different genes has been previously described by MALAWISTA et al. ${ }^{23}$, SADZIENE et al. ${ }^{31,32,33}$, FINGERLE et $a l .{ }^{14}$, MOTALEB et al. ${ }^{28}$, CHARON et al. ${ }^{9}$. The existence of mutant spirochete expressed at atypical cystic morphologies, possibly without periplasmic flagella and decreased expression of outer surface proteins (Osp), justify all the particularities found in BYS.

Due to existence of many distinguishing features in BYS, most of them never described before, it is easy to understand the difficulties found by Brazilian physicians to diagnose this new zoonosis. In fact, it is not an easy task due to the occurrence of many pitfalls during BYS patients' examination. Additionally, we have to understand that this emergent zoonosis is a specific Brazilian health problem and we cannot import answers from countries where LD exists.

Our researchers point out that B. burgdorferi can originate two distinct diseases: LD and BYS, possibly according to geographical and biodiversity conditions. Interestingly, B. burgdorferi had never been identified in South America before, and even in the Southern hemisphere, suggesting the existence of many unanswered questions concerning the relationship between spirochetes, ticks, reservoir animals and ecological conditions. In this respect, we postulate that this complex relationship is associated to emergence of different $B$. burgdorferi mutants, which in turn, causes distinguishing clinical and laboratorial manifestations.

The aim of this study was to characterize the epidemiological, clinical and laboratorial profile of BYS patients, admitted to the IIER, which is a reference hospital for infectious diseases. The frequency of BYS is growing fast, and as we said before, we have to produce new knowledge to answer many unsolved questions concerning this emergent zoonosis. In this respect, we intend to discuss practical medical questions emerged after analyzing the casuistic of BYS admitted to IIER, aiming to help physicians to deal with this original and amazing infectious disease.

\section{MATERIALS AND METHODS}

From July 1990 to July 2006, the IIER sent 171 serum and/or CSF samples with suspicion of BYS to LIM-17 HCFMUSP Lab, to perform serological tests for $B$. burgdorferi, through the Indirect immunosorbent assay (ELISA) ${ }^{29}$ and a modified Western Blotting (WB) $)^{18,40}$.

The diagnosis of BYS was based on the previously described criteria $^{24}$, with final exclusion of infectious diseases and auto immune disorders that could lead to false-positive serology.

From the 171 sera or CSF samples submitted to antibody research, it 
was possible to recover and to analyze 60 patient records. After exclusion of specific infectious or autoimmune diseases, 19 patients $(31.6 \%)$ fulfilled diagnostic criteria and remained with final diagnosis of BYS. In this subgroup of patients, the following aspects were examined: gender, age, origin, tick bite or positive epidemiology, city and state where the infection probably was acquired, and clinical profile.

\section{RESULTS}

Characterization of 60 patients with positive serology to $B$. burgdorferi: Description of the group of 60 patients with positive serology to B. burgdorferi is detailed in Table 1 . Nineteen patients remained as BYS (31.6\%) and 41 patients $(68.4 \%)$ were diagnosed as having other diseases.

\section{Table 1}

Final diagnosis of the 60 patients with positive serology to B. burgdorferi admitted at IIER

\begin{tabular}{lc}
\hline Final Diagnosis & $\mathrm{N}(\%)$ \\
\hline BYS & $19(31.6 \%)$ \\
Rheumatic and/or auto immune disease & $11(18.3 \%)$ \\
Leptospirosis & $4(6.6 \%)$ \\
Dengue & $2(3.3 \%)$ \\
Tuberculosis meningoencephalitis & $2(3.3 \%)$ \\
Brazilian spotted fever & $1(1.6 \%)$ \\
HIV & $1(1.6 \%)$ \\
Salmonellosis & $1(1.6 \%)$ \\
Meningococcemia & $1(1.6 \%)$ \\
Pneumococcal meningitis & $1(1.6 \%)$ \\
Toxocara canis meningitis & $1(1.6 \%)$ \\
Herpes virus meningoencephalitis & $1(1.6 \%)$ \\
Meningitis secondary to mastoiditis & $1(1.6 \%)$ \\
Epidural empyema & $1(1.6 \%)$ \\
Tropical pyomyositis with osteomyelitis & $1(1.6 \%)$ \\
Other causes & $12(20.0 \%)$ \\
\hline Total & $60(100 \%)$ \\
\hline
\end{tabular}

The following diseases had false positive serology for B. burgdorferi: rheumatic or autoimmune diseases $(\mathrm{n}=11 ; 18.3 \%)$; leptospirosis $(\mathrm{n}=$ $4 ; 6.6 \%)$; dengue fever $(n=2 ; 3.3 \%)$; tuberculous meningoencephalitis $(\mathrm{n}=2 ; 3.3 \%)$ and miscellaneous diseases (one patient/each disease), including Brazilian Spotted Fever, HIV, salmonellosis, meningococcemia, pneumococcal meningitis, Toxocara canis meningitis, herpes virus meningitis, meningitis associated to mastoiditis and tropical pyomyositis. Twelve patients $(20 \%)$ remained undiagnosed.

Clinical and epidemiological profile of the 19 patients with final diagnosis of BYS: From the 19 individuals with final diagnosis of BYS, $53 \%$ were women and $47 \%$ men, and the mean age was 26 years ( 4 to 68 years). Four patients were identified at acute disease stage (until three months from disease onset) and fifteen at latent phase.
Regarding the patients origin, thirteen were living in São Paulo city, two came from São Bernardo do Campo, and the other four were from Cotia, Guarulhos, Pirapora do Bom Jesus and Juquitiba, all municipalities belonging to the São Paulo State.

In only five out of 19 patients (25\%), it was possible to determine the exact region where the infection was acquired: the urban area of São Paulo city (two patients), Juquitiba, Cotia and the region around Billings dam.

Signs and symptoms of 19 patients with BYS: The meantime between the tick bite episode and the appearance of first symptoms varied from one day to six years. General "flu-like" symptoms were observed in 15 patients $(78.9 \%)$. Fever was the most frequent symptom, viewed in 11 cases $(57.8 \%)$, isolate or multiple lymphadenomegaly was found in seven patients $(36.8 \%)$ and headache was the third most common symptom, followed by the presence of chills, vomit, odynophagia, diarrhea, cough, hyperhidrosis, and conjuctival hyperaemia (Fig. 1).

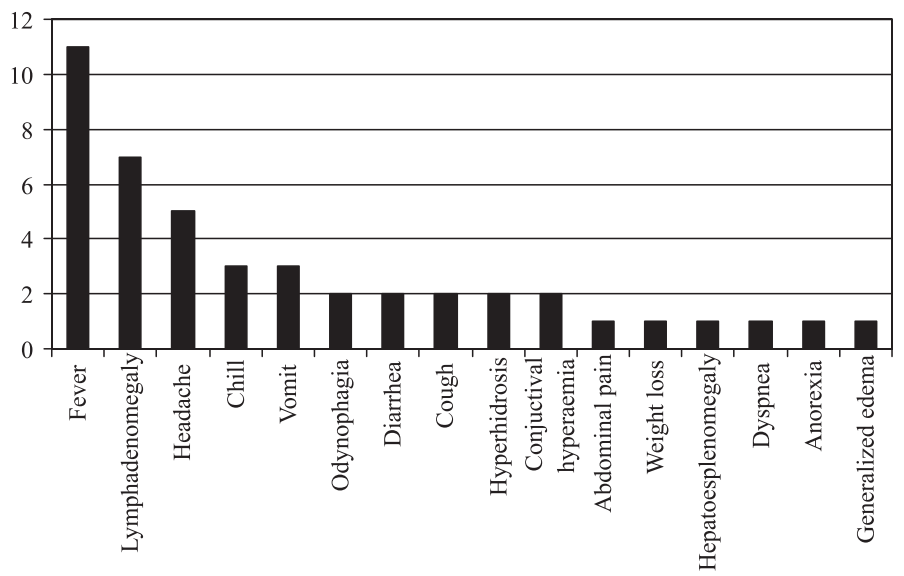

Fig. 1 - List of general symptoms presented by the 19 patients with Baggio-Yoshinari syndrome admitted to IIER.

Six patients $(31.5 \%)$ had skin lesions. Itching acute erythema migrans was observed in one case $(5.2 \%)$, annular secondary erythema in three cases $(15.7 \%)$ and petechiae-like lesions in two cases $(10.5 \%)$.

Regarding the disorders of the locomotor apparatus, six patients $(31.5 \%)$ presented arthralgia or arthritis, and six patients $(31.5 \%)$ had myalgia.

Eight patients (42\%) presented neurological disorders. Meningitis was the most common finding, observed in five cases (26.3\%). It was an isolated symptom in only one patient, three cases had meningoencephalitis and the fifth patient was associated to cranial and peripheral neuritis. Four patients unrolled isolate or multiple cranial neuritis with symptoms of dysarthria, diplopia, facial nerve palsy, eye lid ptosis, etc. Four patients had peripheral sensitive and/or motor neuropathy. Seven out of eight patients presented multiple neurological manifestations (Table 2), which is a prominent feature of neurological involvement related to BYS.

Laboratorial findings of 19 patients with BYS: All studied patients presented antibodies against B. burgdorferi. Two cases had antibodies detected by ELISA only in the cerebrospinal fluid (CSF). Among another 
GOUVEIA, E.A.; ALVES, M.F.; MANTOVANI, E.; OYAFUSO, L.K.; BONOLDI, V.L.N. \& YOSHINARI, N.H. - Profile of patients with Baggio-Yoshinari syndrome admitted at "Instituto de Infectologia Emilio Ribas". Rev. Inst. Med. Trop. Sao Paulo, 52(6): 297-303, 2010.

Table 2

Description of the nervous system disorders found in 19 patients with BYS admitted to the IIER

\begin{tabular}{lll}
\hline Case & CNS & Peripheral Nervous System \\
\hline 1 & & Patellar reflex asymmetry and walk difficulty \\
2 & Meningoencephalitis, ataxia & Dysarthria \\
3 & Meningoencephalitis & $\begin{array}{l}\text { Diplopia } \\
\text { Shoulders and legs weakness, walk difficulty, hypoesthesia trembling }\end{array}$ \\
4 & & Right central facial nerve paralysis, muscular weakness level IV of left leg and level III of right arm \\
6 & & $\begin{array}{l}\text { Right peripheral facial nerve paralysis, walk difficulty, muscular weakness of the legs, paresthesia in boots } \\
\text { and gloves }\end{array}$ \\
7 & Meningitis & Left eyelid ptosis, fixed mydriasis, dysarthria, weakness of right leg strength level IV \\
8 & Meningitis &
\end{tabular}

17 cases, nine (52.9\%) had antibody identified by WB to B. burgdorferi, five $(29.4 \%)$ by ELISA, and only three patients (17.5\%) demonstrated antibodies by WB and ELISA assays at the same time.

Eleven out of 19 patients had the cerebrospinal fluid (CSF) analysis performed. Six samples exhibited a discreet increase of lymphomononuclear cells (less than 200 cells $/ \mathrm{mL}$ ) and seven showed higher CSF protein concentration. Isolated increased protein concentration was demonstrated in one case.

Other laboratorial exams were conducted with all samples to exclude infectious or autoimmune diseases. Haemogram was normal in all cases. Six patients performed VDRL test (CSF and/or blood), three were submitted to serologic analysis for rickettsiosis, four patients for brucellosis, three patients for typhoid fever and five to anti-HIV test. These and other specific exams were negative.

One patient with BYS had positive ANA with homogenous pattern $(>1 / 200)$ and another case presented positive anti-smooth muscle and anti-peroxidase antibodies. These data did not nullify diagnosis of BYS, since this syndrome can present autoimmune features.

Treatment of the 19 patients with BYS: Fifteen of 19 patients were treated with antibiotics and the mean period of treatment time was 22 days, ranging from seven to 46 days. In four cases there was no information concerning a therapeutic scheme on the patients' records. The antibiotics of choice were: ceftriaxone (42\%), amoxicillin (16\%), ceftriaxone associated with doxycycline $(11 \%)$, erythromycin and tetracycline $(5 \%)$.

\section{DISCUSSION}

After careful epidemiological, clinical and laboratorial analysis, 19 out $60(32 \%)$ patients with positive serology to B. burgdorferi, admitted at IIER remained with final diagnosis of BYS. The remaining 41 patients $(68 \%)$ were identified as having autoimmune disease $(\mathrm{N}=11 ; 18.3 \%)$, miscellaneous specific infectious diseases $(\mathrm{N}=18 ; 30 \%)$ and the other 12 patients (20\%) stayed undiagnosed. In other words, this original research is very important for Brazilian physicians, since for the first time it was possible to estimate that $32 \%$ of BYS suspected patients with positive serology for B. burgdorferi displayed final diagnosis of BYS.
As reported before, serology for B. burgdorferi must be interpreted carefully, since it cross reacts with autoimmune and other infectious diseases ${ }^{42}$. Among these diseases we have rheumatoid arthritis, scleroderma, systemic lupus erythematosus, syphilis, leptospirosis, leishmaniasis, tuberculosis, acute virosis, etc. This manuscript also contributed to add a new list of infectious diseases that cross-react with BYS as dengue, Brazilian spotted fever, HIV, salmonellosis, meningococcemia, Toxocara canis meningitis, tropical pyomyositis, etc.

The main learning of this article is to understand that BYS is an infectious disease of increasing interest for Brazilian physicians. However, since its diagnosis is very complex and difficult, the Brazilian physician must be well prepared to recognize it. Certainly, it is not an easy task, mainly at current days, when patient anamnesis is done quickly and often, replaced by expensive complementary subsidiary exams.

It is important to note that only four out of 19 cases were at acute disease stage, when the patients still remembered recent epidemiological and clinical data as those symptoms related to tick bite history or visits to at risk areas. On the contrary, it is easy to understand how difficult was to diagnose the remaining 15 BYS patients belonging to latent disease stage, who underwent BYS symptoms after months or years from acute disease onset.

Clinically, BYS, different to LD, is recognized at acute and latent relapsing stage. The diagnosis and treatment of BYS at early stage is of critical relevance to avoid zoonosis progression to latent stage, when the disease can reveal irreversible sequels. Nowadays, it is shown that misdiagnosed or wrongly treated patients at acute disease stage in the past, can progress to chronic idiopathic rheumatic or neurological diseases. Unfortunately, the Brazilian Government does not consider acute stage of BYS of compulsory notification, since it does not kill people at this phase. Conversely, the economic costs to treat sequels of relapsing symptoms from latent stage are enormous.

Brazilian patients present the typical EM at tick bite site in nearly $50 \%$ of cases. Few cases from this article had EM, possibly because clinical data was gathered retrospectively, and as we said before, patients from latent stage do not inform spontaneously earlier symptoms, and physicians during the anamnesis are not trained to inquire about EM or annular secondary lesions happened at a remote date. Articular and 


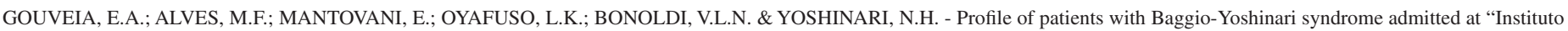
de Infectologia Emilio Ribas". Rev. Inst. Med. Trop. Sao Paulo, 52(6): 297-303, 2010.

neurological symptoms occur in nearly $35 \%$ of BYS patients and similar frequencies were observed in the present study.

Importantly, patients from the present research exhibited the same pattern of neurological involvement reported in previous manuscripts, as the predominance of meningitis, isolated or associated to peripheral or facial neuritis. One of the hallmark features of BYS is the occurrence of simultaneous multiple neurological involvement or its association with arthritis, identified in nearly $50 \%$ of patients. Furthermore, the frequencies of typical recurrent annular secondary skin lesions and "flulike symptoms" decrease as the disease progresses, bringing additional difficulties to identify latent $\mathrm{BYS}^{34}$.

Currently, many other minor or major symptoms are considered useful to diagnose BYS. Patients with BYS display many subjective symptoms as those related to chronic fatigue, fibromyalgia, cognitive disturbance or emotional, labor and social disabilities. Additionally, these patients can mention present or past relevant psychiatric complaints (depression, panic syndrome, schizophrenia-like, suicidal attempt), cardiac (arrhythmias, cardiomegaly) or ocular symptoms (uveitis, optic neuritis, retinal arteritis, papilledema $)^{47}$. Also, skin lesions are not restricted to the presence of EM or annular secondary lesion. Localized scleroderma-like lesion, benign B lymphocytoma, acrodermatitis chronica atrophicans (ACA) and panniculitis have been described in Brazil ${ }^{15,47}$. All these symptoms already identified in BYS, must be remembered by Brazilian physicians when they are performing a patient's anamnesis and physical examination.

Other important learning of this manuscript is to accept that isolated detection of antibodies to B. burgdorferi is not diagnostic for BYS. Indeed, we saw that two thirds of patients with positive serology had autoimmune or other infectious diseases. Also, negative serology for identification of $B$. burgdorferi infection does not rule out the hypothesis of this tick borne zoonosis, since sensibility of both specific assays together (ELISA plus WB) is low, approximately 65\%. Despite all the difficulties, the serology for search of B. burdorferi infection is still an important diagnostic parameter if interpreted carefully, always conjugated to careful anamnesis and physical examinations.

Sometimes, mainly at acute disease stage, the serological results are unnecessary, especially if the patient became ill after tick bite history and presented EM. Similarly, the emergence of arthritis or neurological symptoms after weeks or months following the disease onset, must be related to BYS and deserve specific treatment, even when antibodies to $B$. burgdorferi are absent. It is important to note that antibody titers in the sera of BYS patients are low and oscillating, possibly because we have used antigens of North American origin. Also, as commented before, B. burgdorferi was never cultured or isolated in Brazil. Additionally, Brazilian etiological agent seems to be expressed at cystic form with suppression/inhibition of many genes and proteins, explaining the low repertoire of antibodies to $B$. burgdorferi confirmed by WB analysis. All these features indicate that Brazilian B. burgdorferi is a spirochete which is very well adapted to survive in vertebrate and invertebrate hosts, justifying occurrence of relapsing symptoms.

Searching for antibodies to $B$. burgdorferi in CSF is a good diagnostic option, mainly if we are dealing with a neurologic patient with previous negative serology for $B$. burgdorferi done in the serum. Two of 16 patients of this study had antibodies exclusively in CSF. Interestingly, according to our unpublished experience, cerebrospinal fluid from normal individuals, mostly with headache, does not reveal antibodies against $B$. burgdorferi. Unfortunately, the finding of antibodies to $B$. burgdorferi in CSF is equally unspecific, since cross-reactivity happens with many neurological infections like syphilis, tuberculosis, herpes virus, HIV, HTLV, etc (unpublished data).

The question concerning autoimmunity in BYS deserves further comments. Often, patients with BYS exhibit symptoms present in rheumatic diseases like fever, arthritis, myalgia, muscle weakness, Raynaud's phenomenon, sicca syndrome complaints, vasculitis, photosensibility, neuritis, meningitis, ocular manifestations, skin rashes, etc. Also, laboratorial findings can mimicry autoimmune disorders by appearance of ANA, anti cardiolipin antibodies, antineutrophil cytoplasmic antibodies (ANCA), antitireoperoxidase antibodies, hypergammaglobulinemia, anti neuronal antibodies, etc. For these reasons, physicians must be aware to distinguish BYS from autoimmnune diseases. Additionally, we have found anemia, leucopenia, thrombocytopenia, transaminases increase and bilirrubinemia, mainly in BYS patients suspected of co-infections with other tick-borne diseases like babesiosis, ehrlichiosis, bartonellosis and rickettsiosis ${ }^{7,35}$.

We assume that the frequency of BYS at the IIER in the studied period is higher than demonstrated in this manuscript. First of all, we excluded patients with symptoms of BYS without positive serology for $B$. burgdorferi, even when autoimnune or other infections were ruled out. Also, it is plausible to admit that among the 12 undiagnosed patients (20\%) with positive serology for B. burgdorferi, without autoimmune or other specific infection, a new careful anamnesis of the past history or follow up looking for eventual relapsing symptoms in the future, could contribute to an increase in the frequency of BYS positivity.

A few number of patients offered safe information about where they were infected. It was not a surprise that two patients acquired the disease inside the urban area of São Paulo, because many peripheral urban regions exhibit rich vegetation with presence of wild and domestic animals. Previous reports had already demonstrated BYS onset, within São Paulo city, showing that this zoonosis is also a cosmopolitan disease ${ }^{42,43}$. Recently, we have performed PCR for B. burgdorferi using $f g E$ primer and preliminary unpublished results confirmed that bovines and horses participate in the BYS transmission (unpublished data). Also B. burgdorferi has been identified in ticks from genus Rhipicephalus, which infest these domestic animals (unpublished data). These reports confirm that epidemiology of BYS is very different from those observed in $\mathrm{LD}$, explaining why the zoonosis behavior is so different in our country.

In general, people are infected casually at small rural municipalities around São Paulo city or in forested areas close to the beaches. It is important to know that premature tick removal from the skin before 24 hours avoids spirochete transmission. People must wear clear clothes, boots, tick repellents and search carefully for ticks after visiting at risk areas.

As far as the treatment is concerned, 15 out of 19 patients with BYS were submitted to antibiotic therapy, most of the cases with ceftriaxone $2 \mathrm{~g} /$ day, given over an average of 22 days. Unfortunately, it was not possible to obtain additional information about the other four patients' records, neither about the evolution of the patients treated with antibiotics. 
GOUVEIA, E.A.; ALVES, M.F.; MANTOVANI, E.; OYAFUSO, L.K.; BONOLDI, V.L.N. \& YOSHINARI, N.H. - Profile of patients with Baggio-Yoshinari syndrome admitted at "Instituto de Infectologia Emilio Ribas". Rev. Inst. Med. Trop. Sao Paulo, 52(6): 297-303, 2010.

Currently, acute cases of BYS are treated with doxycycline $100 \mathrm{mg}$ b.i.d. or amoxicillin, $500 \mathrm{mg}$ each q.i.d for 30 days. Relapsing symptoms are treated with ceftriaxone, $2 \mathrm{~g}$ a/day for 30 days with additional use of doxycycline $100 \mathrm{mg}$ twice a day for three months or continuous use of doxycycline for four months. In general, ceftriaxone or penicillin 20 millions/day/IV are indicated when neurological symptoms are present. Hydroxychloroquine $400 \mathrm{mg}$ /day given for a prolonged period of time seems to be a useful drug to avoid appearance of recurrent symptoms. Unfortunately, we are not sure about the real role and importance of antibiotic treatment at latent stage of BYS, because autoimmune disorders are equally observed at this disease stage. Otherwise, spirochetes have been identified by PCR procedure in some patients with BYS at latent stage, after years from disease onset. Surprisingly, in some cases, patients reported previous treatment with antibiotics (unpublished data).

The prevalence of BYS in Brazil is unknown, but the number of suspect cases is growing fast, since physicians of different specialties are starting to recognize this new tick-borne disease. However, it has been a very difficult task to spread knowledge on BYS, because medical students are accustomed to learn about LD in International Medical Textbooks, and we know that this North American and Eurasian zoonosis is completely different. The achievement of knowledge on BYS has been done slowly due to its complexity. We believe that this manuscript can be very helpful for Brazilian physicians, in helping them avoid pitfalls usually found in BYS patients.

Unfortunately, often we are censured by external referees since we cite our own articles. However, we have to understand that this is a necessary procedure since we are dealing with a new Brazilian infectious disease and we need to develop our own learning, instead of bringing knowledge from foreign countries.

BYS must receive great attention from Public Health managers due to its high morbidity and propensity to cause irreversible sequels. Researches and results on BYS have been an enormous scientific challenge, which demand extensive cooperation with experts of different areas, in an attempt to full disclosure this intriguing Brazilian tick borne zoonosis. Finally, it has not been an easy mission to assume responsibilities to research and to transmit knowledge of this unbelievable disease, mainly because it involves deep conceptual changes concerning host versus microorganism relationship.

\section{RESUMO}

\section{Perfil dos pacientes com Síndrome Baggio-Yoshinari admitidos no "Instituto de Infectologia Emilio Ribas"}

O objetivo do estudo foi avaliar o perfil epidemiológico, clínico e laboratorial dos pacientes com Síndrome Baggio-Yoshinari (SBY), internados no Instituto de Infectologia Emilio Ribas, São Paulo, Brasil, no período de julho de 1990 a julho de 2006. SBY é uma nova doença transmitida por carrapatos, causada pela Borrelia burgdorferi sensu lato, que se assemelha a Doença de Lyme (DL), exceto pelas particularidades epidemiológicas, clínicas e laboratoriais. A partir dos registros de 60 pacientes com sorologia positiva para $B$. burgdorferi pelos métodos de ELISA e Western-blotting, 19 casos foram diagnosticados como SBY, de acordo com critérios adotados pelo LIM-17 HCFMUSP, laboratório de referência para a pesquisa de SBY no Brasil. Os outros 41 pacientes restantes foram classificados como tendo infecções diversas ou processos auto-imunes. O início dos sintomas no grupo SBY variou de um dia a seis anos. Quatro dos 19 pacientes foram incluídos na fase aguda da doença e 15 na fase latente. Os sintomas gerais inespecíficos foram identificados em quase todos os casos, com altas freqüências de febre $(78,9 \%)$ e linfoadenomegalia $(36,8 \%)$. Seis pacientes tiveram lesões de pele $(31,5 \%)$; seis artralgia ou artrite $(31,5 \%)$ e oito sintomas neurológicos (42\%). Curiosamente, dois pacientes apresentaram anticorpos para B. burgdorferi exclusivamente no líquido cefalorraquidiano. Uma vez que a SBY é uma zoonose emergente brasileira e seu diagnóstico é complexo, todo o conhecimento novo sobre SBY deve ser difundido para os médicos brasileiros, com o objetivo de ensiná-los a diagnosticar esta surpreendente doença transmitida por carrapatos, evitando-se a sua progressão para sequelas crônicas irreversíveis.

\section{REFERENCES}

1. Abel IS, Marzagão G, Yoshinari NH, Schumaker TTS. Borrelia-like spirochetes recovered from ticks and small mammals collected in the Atlantic Forest Reserve, Cotia County, State of São Paulo, Brazil. Mem Inst Oswaldo Cruz. 2000;95:621-4.

2. Baranton G, Assous M, Postic D. Three bacterial species associated with Lyme borreliosis Clinical and diagnostic implications. Bull Acad Natl Med. 1992;176:1075-86.

3. Barbour AG, Maupin GO, Teltow GJ, Carter CJ, Piesman J. Identification of an uncultivable Borrelia species in the hard tick Amblyomma americanum: possible agent of a Lyme disease-like illness. J Infect Dis. 1996;173:403-9.

4. Barros PJL. Caracterização clínica e laboratorial da doença de Lyme no Brasil, através de métodos imunológicos e reação em cadeia de polimerase. [tese]. São Paulo: Faculdade de Medicina da Universidade de São Paulo; 2000.

5. Barros PJL, Levy LH, Monteiro FGV, Yoshinari NH. Doença de Lyme: acometimento cutâneo e tratamento das fases iniciais. Rev Assoc Med Bras. 1993;39:170-2.

6. Barros-Battesti DM, Yoshinari NH, Bonoldi VL, De Castro GA. Parasitism by Ixodes didelphidis and I. loricatus (Acari:Ixodidae) on small wild mammals from an Atlantic Forest in the State of São Paulo, Brazil. J Med Entomol. 2000;37:820-7.

7. Bonoldi VLN. Estudo laboratorial de agentes infecciosos transmitidos por carrapatos em pacientes com doença de Lyme-símile brasileira (Síndrome Baggio-Yoshinari) [tese]. São Paulo: Faculdade de Medicina da Universidade de São Paulo; 2009.

8. Canica MM., Nato F, du Merle L, Mazie JC, Baranton G, Postic D. Monoclonal antibodies for identification of Borrelia afzelii sp. nov. associated with late cutaneous manifestations of Lyme borreliosis. Scand J Infect Dis. 1993;25:441-8.

9. Charon NW, Goldstein SF, Marko M, Hsieh C, Gebbardt LL, Motalb MA, et al. The flat-ribbon configuration of the periplasmic flagella of Borrelia burgdorferi and its relationship to motility and morphology. J Bacteriol. 2009;191:600-7.

10. Costa IP. Pesquisa de anticorpos anti-Borrelia e do agente etiológico em soro e liquor de pacientes com manifestações clínicas compatíveis com a Doença de Lyme, no Estado de Mato Grosso do Sul [tese]. São Paulo: Faculdade de Medicina da Universidade de São Paulo; 1998.

11. Costa IP, Bonoldi VLN, Yoshinari NH. Perfil clínico e laboratorial da doença de Lyme-símile em Mato Grosso do Sul: análise de 16 pacientes. Rev Bras Reumatol. 2001;41:142-50.

12. Costa IP, Bonoldi VL, Yoshinari NH. Search for Borrelia sp. in ticks collected from potential reservoirs in an urban forest reserve in the State of Mato Grosso do Sul, Brazil: a short report. Mem Inst Oswaldo Cruz. 2002;97:631-5.

13. Dressler F, Ackermann R, Steere AC. Antibody responses to the three genomic groups of Borrelia burgdorferi in European Lyme borreliosis. J Infect Dis. 1994;169:313-8. 

de Infectologia Emilio Ribas". Rev. Inst. Med. Trop. Sao Paulo, 52(6): 297-303, 2010.

14. Fingerle V, Goettner G, Gern L, Wilske B, Schulte-Spechtel U. Complementation of a Borrelia afzelii OspC mutant highlights the crucial role of OspC for dissemination of Borrelia afzelii in Ixodes ricinus. Int J Med Microbiol. 2007;297:97-107.

15. Fonseca AH, Salles RS, Salles SAN, Madureira RC, Yoshinari NH. Borreliose de Lyme símile: uma doença emergente e relevante para a Dermatologia no Brasil. An Bras Dermatol. 2005;80:171-8

16. Gauditano G, Bonoldi VLN, Costa IP, Battesti DMB, Barros PJL, Fonseca AH, et al. Síndrome de Lyme-símile ou complexo infecto-reacional do carrapato - síndrome de Baggio-Yoshinari. Rev Paul Reumatol. 2005;4:16-7.

17. Gauditano G, Yoshinari NH. Doença de Lyme/Síndrome de Baggio-Yoshinari. In: Veronesi R, Focaccia R, editores. Tratado de Infectologia. $4^{\mathrm{a}}$ ed. São Paulo: Editora Atheneu; 2009. p. 1359-79.

18. Grodzicki RL, Steere AC. Comparison of immunoblotting and indirect enzyme-linked immunosorbent assay using different antigens preparations for diagnosis of early Lyme disease. J Infect Dis. 1988;157:790-7.

19. Johnston BL, Conly JM. Lyme disease: is it or is it not? Can J Infect Dis Med Microbiol. $2005 ; 16: 325-8$.

20. Kawabata H, Tashibu H, Yamada K, Masuzawa T, Yanagihara Y. Polymerase chain reaction analysis of Borrelia species isolated in Japan. Microbiol Immunol. 1994;38:591-8.

21. Kristoferitsch W. Lyme borreliosis in Europe. Neurologic disorders. Rheum Dis Clin North Am. 1989;15:767-74

22. Liebling MR, Nishio MJ, Rodriguez A, Sigal LH, Jin T, Louie JS. The polymerase chain reaction for the detection of Borrelia burgdorferi in human body fluids. Arthritis Rheum. 1993;36:665-75.

23. Malawista SE, Montgomery RR, Wang XM, Fu LL, Giles SS. Geographic clustering of an outer surface protein A mutant of Borrelia burgdorferi. Possible implications of multiple variants for Lyme disease persistence. Rheumatology (Oxford). 2000;39:53741.

24. Mantovani E, Costa IP, Gauditano G, Bonoldi VLN, Higuchi ML, Yoshinari NH Description of Lyme disease-like syndrome in Brazil. Is it a new tick borne disease or Lyme disease variation? Braz J Med Biol Res. 2007;40:443-56.

25. Mantovani E, Gauditano G, Bonoldi VLN, Yoshinari NH. Análise clínica e sorológica de pacientes com síndrome infecto-reacional Lyme-símile. Rev Paul Reumatol. 2007;6:29.

26. Mantovani E. Identificação do agente etiológico da doença de Lyme-símile brasileira (síndrome Baggio-Yoshinari). [tese]. São Paulo: Faculdade de Medicina da Universidade de São Paulo; 2010.

27. Masters E, Granter S, Duray P, Cordes P. Physician-diagnosed erythema migran and erythema migrans-like rashes following Lone Star tick bites. Arch Dermatol. 1998;134:955-60.

28. Motaleb MA, Sal MS, Charon NW. The decrease in FlaA observed in a flaB mutant of Borrelia burgdorferi occurs posttranscriptionally. J Bacteriol. 2004;186:3703-11.

29. Naka EN, Costa IP, Arão CSB, Soares CO, Yoshinari NH. Pesquisa de anticorpos antiBorrelia e anti-Babesia e soro de crianças com manifestações clínicas e epidemiologia compatíveis com a doença de Lyme-simile no Estado de Mato Grosso do Sul. Rev Bras Reumatol. 2008;48(2):74-85

30. Ojaimi C, Davidson BE, Girons IS, Old IG. Conservation of gene arrangement and an unusual organization of rRNA genes in the linear chromosomes of the Lyme disease spirochaetes Borrelia burgdorferi, B. garinii and B. afzelii. Microbiology, 1994;140:2931-40
31. Sadziene A, Thomas DD, Bundoc VG, Holt SC, Barbour AG. A flagella-less mutant of Borrelia burgdorferi. Structural, molecular, and in vitro functional characterization. J Clin Invest. 1991;88:82-92.

32. Sadziene A, Barbour AG, Rosa PA, Thomas DD. An OspB mutant of Borrelia burgdorferi has reduced invasiveness in vitro and reduced infectivity in vivo. Infect Immun. 1993;61:3590-6

33. Sadziene A, Thomas DD, Barbour AG. Borrelia burgdorferi mutant lacking Osp: biological and immunological characterization. Infect Immun. 1995;63:1573-80.

34. Shinjo SK, Gauditano G, Marchiori PE, Bonoldi VLN, Costa IP, Manovani E, et al. Neurological manifestations in Baggio-Yoshinari syndrome (Brazilian Lyme diseaselike syndrome). Braz J Rheumatol. 2009;49:492-505.

35. Spolidorio MG, Labruna MB, Machado RZ, Moraes-Filho J, Zago AM, Donatele DM, et al. Survey for tick-borne zoonoses in the state of Espirito Santo, southeastern Brazil. Am J Trop Med Hyg. 2010;83:201-6.

36. Steere AC. Lyme disease. N Engl J Med. 1989;321:586-96.

37. Steere AC. Lyme disease. N Engl J Med. 2001;345:115-25.

38. Talhari S, Santos MNS, Talhari C, Ferreira LCL, Silva Jr RM, Zelger B, et al. Borrelia burgdorferi "sensu lato" in Brazil: occurrence confirmed by immunohistochemistry and focus floating microscopy. Acta Tropica .2010;115:200-4

39. Yoshinari NH, Steere AC, Cossermelli W. Revisão da borreliose de Lyme. Rev Assoc Med Bras. 1989;35:34-8

40. Yoshinari NH, Barros PJ, Cruz FCM, Oyafuso LK, Mendonça M, Baggio D, et al. Clínica e sorologia da doença de Lyme no Brasil. Rev Bras Reumatol. 1992;32 (Supl.):57.

41. Yoshinari NH, Oyafuso LK, Monteiro FG, Barros PJ, Cruz FC, Ferreira LGE, et al Doença de Lyme. Relato de um caso observado no Brasil. Rev Hosp Clin Fac Med Sao Paulo. 1993;48:170-4

42. Yoshinari NH, Barros PJL, Fonseca AH, Bonoldi VL, Barros-Battesti DM, Schumaker TT. Borreliose de Lyme. Zoonose emergente de interesse multidisciplinar. Newslab. 1995;12:90-104

43. Yoshinari NH, Barros-Battesti PJ, Gauditano G, Fonseca AH. Report of 57 cases of Lyme-like disease (LLD) in Brazil. Arthritis Rheum. 1999;43(Suppl):S188.

44. Yoshinari NH, Abrão MG, Bonoldi VLN, Soares CO, Madruga CR, Scofield A, et al. Coexistence of antibodies to tick-borne agents of Babesiosis and Lyme borreliosis in patients from Cotia County, State of São Paulo, Brazil. Mem Inst Oswaldo Cruz. 2003;98:311-8.

45. Yoshinari NH, Gonçalves R. Doença de Lyme-símile no Brasil. Diagn Tratamento. 2003;8:61-70.

46. Yoshinari NH, Vasconcelos SA, Tiriba AC, Gauditano G, Mantovani E, Bonoldi VLN. Report of unusual presence of latent microorganisms in animals: a risk to research and health of employees? Braz J Rheumatol. 2009;49:517-28.

47. Yoshinari NH, Mantovani E, Bonoldi VLN, Marangoni RG, Gauditano G. Doença de Lyme-símile brasileira ou síndrome Baggio-Yoshinari: zoonose exótica e emergente transmitida por carrapatos. Rev Assoc Med Bras. 2010;56:363-9.

Received: 7 April 2008

Accepted: 3 September 2010 